\title{
Gene Expression of the Endothelin-1 in Vasospastic Flap Pedicle - an Experimental Study on a Porcine Model
}

\author{
Petr Hýža ${ }^{1}$, Libor Streit ${ }^{1}$, Eduard Gopfert ${ }^{2}$, Daniel Schwarz ${ }^{3}$, Michal Masařík ${ }^{4}$, \\ Michal Jurajda ${ }^{4}$, Anna Vaškư ${ }^{4}$, Jiří Veselý ${ }^{1}$ \\ ${ }^{1}$ Clinic of Plastic and Aesthetic Surgery, Masaryk University, Brno, Czech Republic \\ ${ }^{2}$ Veterinary Research Institute, Brno, Czech Republic \\ ${ }^{3}$ Institute of Biostatistics and Analyses, Masaryk University, Brno, Czech Republic \\ ${ }^{4}$ Department of Pathological Physiology, Masaryk University, Brno, Czech Republic \\ Received January 14, 2010 \\ Accepted March 8, 2010
}

\begin{abstract}
The aim of this study was to evaluate the amount of Endothelin-1 (ET-1) gene expression in the vasospastic vessel of the flap pedicle to prove or disprove the role of ET-1 gene expression in pathogenesis of mechanically induced vasospasm. The vasospasm was induced by the tension on the pedicle of the pedicled caudal superficial epigastric flap on 8 pigs. Laser Doppler was used for peripheral blood flow measurement. Specimens from the vasospastic vessel (group of specimens $\mathrm{B}$ ) and from the flap border with no vasospasm (control group A) were taken $2 \mathrm{~h}$ after the stimulus initiation. Detection of ET-1 mRNA by Quantitative Real-Time RT-PCR was performed. $\beta$-actin was selected as an acceptable reference gene. Relative gene expression data were given as the $\mathrm{n}$-fold change in transcription of target genes normalized to the endogenous control. Relative gene expressions and time indicators of vasospasm were compared in both groups. No significant difference of the ET-1 gene expressions was found between groups A and B $(p=0.505)$. No correlation between the duration of vasospasm and ET-1 gene expression was found as well $(p=0.299)$. In conclusion, the expression of the ET-1 gene in the mechanically induced vasospastic vessel of the pedicled flap was not significantly increased. In this study, the causality of the vasospasm pathogenesis and gene expression of ET-1 was not proven.
\end{abstract}

Vasospasm, pathogenesis, microsurgery, pig

Free flap transfer is a routine technique in plastic surgery. Vasospasm usually develops during flap dissection (Jurell et al. 1983; Goshen et al. 1985). It is a localized and usually persistent vascular contraction that may be caused by a local injury. A prolonged vasospasm may cause a complete obstruction of the vessel and result in a flap loss (Kemp et al. 1993, Moskowitz et al. 1995, Evans et al. 1997; Gurlek et al. 1997).

Endothelial continuity is a basic condition for intact blood flow through the flap. The most frequent cause of endothelial dysfunction is the presence of arterial or venous anastomosis related to endothelial damage. With subendothelial surface denudation, the thrombus is formed and vasoactive substances that cause vasoconstriction are released. The endothelial dysfunction may also change concentrations of the nitric oxide and Endothelin-1 (ET-1) in the close tissue and aggravate vasospasm (Chong et al. 2003).

In our previous studies on the rodent model, vasospasm was provoked by the axial tension applied on the pedicle vessels and magnesium sulphate was proved as the vasospasm releasing drug (Hyza et al. 2009a,b). The aim of this study was to evaluate the amount of ET-1 gene expression in the vasospastic vessel of the flap pedicle to prove the role of ET-1gene expression in pathogenesis of the mechanically provoked vasospasm.

\section{Material and Methods}

The study was done at Veterinary Research Institute Brno and it was approved by the Commission for Animal Welfare. Eight pigs, crossbreeds of White Noble (50\%) and Landrace (50\%), were operated on under general anaesthesia. The average weight of the pigs was $57 \mathrm{~kg}$. The surgery was conducted under standard temperature

Address for correspondence:

MUDr. Petr Hýža

Klinika plastické a estetické chirurgie

Berkova 34, Brno 61200, Czech Republic
Phone: +420541582166

E-mail: petr.hyza@fnusa.cz

http://www.vfu.cz/acta-vet/actavet.htm 
conditions $\left(23^{\circ} \mathrm{C}\right)$ in general anaesthesia using TKX (tiletamin-zolazepam + xylazine + ketamine). The specimens of the vessels were taken from the pedicles of the flaps based on caudal superficial epigastric arteries. The flaps were raised on the abdomen and the peripheral blood flow was measured using laser Doppler (Plate I, Fig. 1a). The vasospasm was induced by the tension on the pedicle using $160 \mathrm{~g}$ weight for $5 \mathrm{~min}$ and then the tension was released. On the flap saline was applied on the pedicle as a control group and the measurement of the blood perfusion was done for a minimum of $30 \mathrm{~min}$. The perfusion recording signals were exported from the control software package of the laser Doppler flowmeter into ASCII format files. Two important time periods (tB and tC) were extracted from the signals with use of MATLAB (Math Works, Natick, MA, U.S.A) scripts (Fig. 1b). Time period $\mathrm{tB}$ represented the time to the beginning of reperfusion; $\mathrm{tC}$ represented the time to maximum value of reperfusion. The specimens of the vasospastic pedicle vessels of the flaps were taken $2 \mathrm{~h}$ after the flap elevation (Group B) and fixed in a RNAlater RNA Stabilization Reagent (Qiagen, Germany) which immediately stabilized RNA in tissue samples to preserve the gene expression profile, and after this the samples were stored at $-80{ }^{\circ} \mathrm{C}$. Also, specimens of the intact vessel on the periphery of the flap were taken as a control and fixed as mentioned above (Group A). The specimens were then processed in a laboratory of Department of Pathological Physiology, Faculty of Medicine at Masaryk University, Brno.

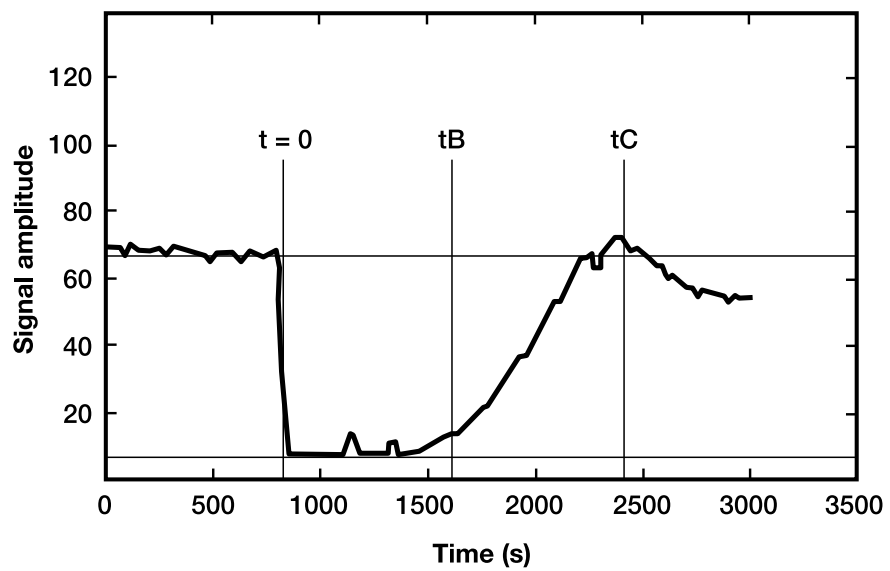

Fig. 1b. The perfusion curve obtained using laser Doppler measurement

The points $\mathrm{t}=0, \mathrm{tB}, \mathrm{tC}$ were automatically detected by computer processing and the duration of vasospasm and reperfusion was measured.

RNA isolation and Quantitative Real-Time RT-PCR

Before RT-PCR analysis the samples were homogenized in RLT buffer (Qiagen, Germany) by Turrax T10 basic (IKA, Germany) for 2 min on ice. Subsequently, the homogenates were used for RNA isolation by Rneasy Mini kit (Qiagen, Germany) as recommended by the manufacturer. Total RNA $(2 \mu \mathrm{g})$ was reverse transcribed to cDNAs using Omniscript RT kit (Qiagen, Germany) according to manual instructions. TaqMan ${ }^{\circledR}$ Gene Expression Assays (Applied Biosystems, Warrington, United Kingdom) were used for ET-1 detection. In order to choose an appropriate reference gene, we analyzed different pig housekeeping genes for tissue samples and elected $\beta$-actin as an acceptable reference gene for the tissue samples. Quantitative Real-Time RT-PCR was performed with TaqMan ${ }^{\circledR}$ Gene Expression Assays (Applied Biosystems) containing intron-spanning primers: Endothelin - Ss03392455 m1 and $\beta$-actin - Ss03376563_uH. Quantitative Real-Time RT-PCR was performed in an amplification mixture with a volume of $20 \mu \mathrm{l}$. The target gene amplification mixture contained $10 \mu \mathrm{LX}$ TaqMan ${ }^{\circledR}$ Universal PCR Master Mix, $1 \mu 1$ primer of the appropriate endothelin or $\beta$-actin (Gene Expression Assay), $10 \mathrm{ng}$ template cDNA diluted in $5 \mu \mathrm{l}$ nuclease free water, and $3 \mu 1$ nuclease free water. PCR reaction conditions comprised $2 \mathrm{~min}$ at $50{ }^{\circ} \mathrm{C}, 10 \mathrm{~min}$ at $95{ }^{\circ} \mathrm{C}$ followed by 40 cycles of $15 \mathrm{~s}$ at $95{ }^{\circ} \mathrm{C}$ and 1 min at $60{ }^{\circ} \mathrm{C}$. Fluorescence generation due to TaqMan ${ }^{\circledR}$ probe cleavage by the 5'-3' exonuclease activity of the DNA polymerase was measured with the ABI PRISM 7000 Sequence Detection System (Applied Biosystems). All samples were amplified in triplicate. To cover the range of expected Values that included our amount of target mRNA, a standard curve of six serial dilutions from $50 \mathrm{ng}$ to $500 \mathrm{pg}$ of pooled cDNA was analyzed by Sequence Detection Software (SDS 1.9.1., Applied Biosystems). Results were imported into Microsoft Excel for further analysis. Comparable cDNA amounts in the experimental samples were calculated according to the standard curve method. Relative gene expression data were given as the $n$-fold change in transcription of target genes normalized to the endogenous control. The tissue sample with the lowest detectable target gene expression was arbitrarily applied as the calibrator and the results were calculated in relation to the calibrator's expression level. 


\section{Results}

Table 1. Relative expression of ET-1 in groups A and B

\begin{tabular}{|c|c|c|r|r|}
\hline Animal No. & Group & Relative expression & $\mathrm{tB}[\mathrm{s}]$ & \multicolumn{1}{c|}{$\mathrm{tC}[\mathrm{s}]$} \\
\hline 1 & $\mathrm{~A}$ & 0.009562918 & 0.0 & 0.0 \\
1 & $\mathrm{~B}$ & 0.025120343 & 1435.2 & 1619.6 \\
\hline 2 & $\mathrm{~A}$ & 0.006243915 & 0.0 & 0.0 \\
2 & $\mathrm{~B}$ & 0.012216713 & 374.1 & 384.4 \\
\hline 3 & $\mathrm{~A}$ & 0.012259127 & 0.0 & 0.0 \\
3 & $\mathrm{~B}$ & 0.016250936 & 101.6 & 1183.9 \\
\hline 4 & $\mathrm{~A}$ & 0.009322935 & 0.0 & 0.0 \\
4 & $\mathrm{~B}$ & 0.010610722 & 979.4 & 1734.7 \\
\hline 5 & $\mathrm{~A}$ & 0.008608634 & 0.0 & 0.0 \\
5 & $\mathrm{~B}$ & 0.004613253 & 244.6 & 1853.8 \\
\hline 6 & $\mathrm{~A}$ & 0.006699798 & 0.0 & 0.0 \\
6 & $\mathrm{~B}$ & 0.004124209 & 3.5 & 96.4 \\
\hline 7 & $\mathrm{~A}$ & 0.010635267 & 0.0 & 0.0 \\
7 & $\mathrm{~B}$ & 0.010296753 & 683.0 & 1570.7 \\
\hline 8 & $\mathrm{~A}$ & 0.012824088 & 0.0 & 0.0 \\
8 & $\mathrm{~B}$ & 0.012473412 & 273.9 & 1708.0 \\
\hline
\end{tabular}
normal distribution. The null hypothesis: "There is no dependence between values of mRNA relative expression and values of vasospasm duration (tB, tC)" could not be refused at $p_{\mathrm{tB}}=0.299, p_{\mathrm{tC}}=0.934, \rho_{\mathrm{tB}}=0.428, \rho_{\mathrm{tC}}=0.048$ ( $\rho$-the Spearman coefficient of correlation) .

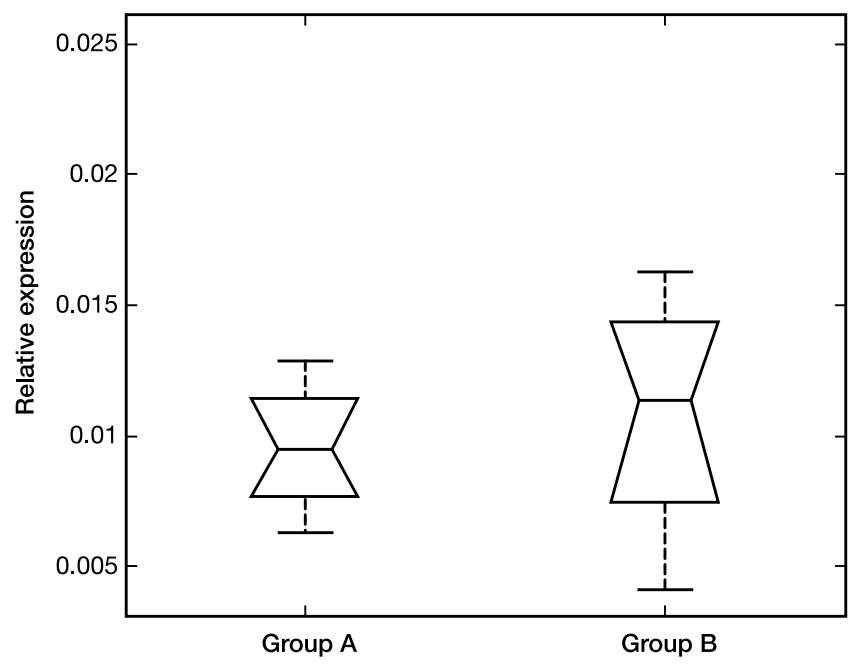

Fig. 2. Relative ET-1 mRNA expression in the vasospastic and control vessels of the pedicle Group A (control): the specimens of the control vessels without vasospasm induction Group B: the specimens of the vessels with induced vasospasm

\section{Discussion}

The pathogenesis of vasospasm resulting from pulling the pedicle is still not clear. In a study on pigs, Wingard et al. (1995) proved that stretching arterial smooth muscle to $1.2 \times$ its resting length, maximal phosphorylation of myosin light chains appears and 
vasospasm develops. This effect is known as a myogenic response (Wingard et al. 1995). Also, the endothelium may suffer from some functional or structural changes that can develop from either minor ruptures or hypoxia or both (Blann et al. 1993; Lantieri et al. 2003; Masaki et al. 2006). Smooth muscle contraction of skin vessels is also regulated by nervous (sympathetic neural fibres) and endocrine/paracrine system. Endothelial factors modulate the effect of norepinephrine released by sympathetic nerves and endocrine and local metabolic substances. Physiological blood flow in skin vessels is maintained by optimal balance in regulation (Table 2).

Table 2. Substances acting in regulation of the vascular tone

\begin{tabular}{|c|c|}
\hline Vasoconstriction & Vasodilatation \\
\hline \multicolumn{2}{|c|}{ Substances from vascular wall, not-coming from endothelium } \\
\hline $\begin{array}{l}\text { 1. Eicosanoids: } \\
\text { - } \text { PGF }_{2} \alpha \text { (vessel myocytes) } \\
\text { - } \text { LTC }_{4} \text { (leukocytes) } \\
\text { 2. Superoxide radicals } \\
\text { (ischemia/reperfusion injury) }\end{array}$ & $\begin{array}{l}\text { 1. Eicosanoids: } \\
\text { - Prostaglandin } \mathrm{PGE}_{2} \text { (vessel myocytes) } \\
\text { 2. Lactate, adenosine, kalium and } \mathrm{H}^{+} \\
\text {ions (hypoxia, ischaemia) }\end{array}$ \\
\hline \multicolumn{2}{|c|}{ Substances coming from endothelium } \\
\hline $\begin{array}{l}\text { Endothelial factors: } \\
\text { - Endothelin-1 }\end{array}$ & $\begin{array}{l}\text { Endothelial factors: } \\
\text { - EDRF, Nitric oxid } \\
\text { - Prostacyclin PGI }\end{array}$ \\
\hline \multicolumn{2}{|c|}{ Substances coming from blood } \\
\hline 5-HT (serotonin) & 5-HT (serotonin) \\
\hline Thrombin & Histamine \\
\hline TXA (thrombocytes) & Bradykinin \\
\hline
\end{tabular}

The family of endothelins consists of three closely related peptides, ET1-ET-3, each encoded by distinct genes (Inoue et al. 1989). ET-1 is the most potent vasoconstrictor between endothelins. Peptide ET-1 is synthesized within endothelial cells from a biologically inactive precursor (big ET-1) by hydrolysis predominantly mediated by the EndothelinConverting Enzyme (ECE1) localised in the plasma membrane. Other enzyme ECE-2, optimally working at an acidic $\mathrm{pH}$, may occur under pathophysiological conditions like hypoxia (Emoto et al. 1995; Barnes et al. 1998, Russell et al. 1999; Davenport et al. 2006).

Some amount of endothelin is secreted into the circulation, but the majority of endothelin is secreted by a paracrine way and contributes to maintenance of basal vascular tone (Haynes et al. 1994). Big endothelins, ET-1 and ET-3 are detectable in blood, but their concentrations are low and represent about $25-30 \%$ of endothelin formed by the endothelial cells. The major part of this amount is formed by big endothelin. ET-1 is a powerful vasocostrictor. Recent studies proved that ischemia induces an increase of ET-1 mRNA expression and consequently this elevation may cause vasospasm (Tsui et al. 2004; Khalil et al. 2006).

Based on the above, we may assume that vasospasm originates by combination of myogenic response of the vessel to mechanical irritation during dissection and effect of paracrine substances released mainly by damaged or dysfunctional endothelial cells and degranulated thrombocytes (Jurell et al. 1983; Goshen et al. 1985; Pang et al 1993; Vans et al. 1997; Chong et al. 2003). In this study, the results have not confirmed expected higher expression of the ET-1 gene in the vessels, where vasospasm was mechanically induced. This could be due to a small number of cases in the study or the origin of mechanically induced vasospasm could have been related mainly to other regulatory pathways. Even though we did not prove increased ET-1 gene expression at the vasospastic vessel, we still can expect some effect of ET-1 stored and released from Weibel-Palade bodies after an external pathophysiological stimulus. We can anticipate two possible ways of ET-1 release: degranulation initiated by regulated or constituted pathway or by cell destruction. Proportion of ET-1 to big ET-1 is strongly influenced by ECE-1 and ECE-2 activities. From this viewpoint, the therapeutic effect of non-selective ET-1 antagonists in combination with local use of magnesium sulphate may be anticipated (Vachieri et al. 2009). Increased 
expression of ET-1 in the vessel with vasospasm induced by mechanical stimulation of the flap pedicle was neither confirmed nor disproved. Indirect evidence of participation of ET-1 in the vasospasm could be further studied by testing non-selective ET-1 inhibitors.

\section{Acknowledgement}

The work was supported by the grant IGA No.8368-5.

\section{References}

Barnes K, Brown C, Turner AJ 1998: Endothelin-converting enzyme, ultrastructural localization and its recycling from the cell surface. Hypertension 31: 3-9

Blann AD, Naqvi T, Waite M, McCollum CN 1993: Von Willebrand factor and endothelial damage in essential hypertension. J Hum Hypertens 7: 107-111

Chong AY, Blann AD, Lip GYH 2003: Assessment of endothelial damage and dysfunction: observations in relation to heart failure. Q J Med 96: 253-267

Davenport AP, Maguire JJ 2006: Endothelin. Handb Exp Pharmacol 176: 295-329

Emoto N, Yanagisawa M 1995: Endothelin-converting enzyme-2 is a membrane-bound, phosphoramidonsensitive metalloprotease with acidic pH optimum. J Biol Chem 270: 15262-15268

Evans GR, Gherardini G, Gurlek A, Langstein H, Joly GA, Cromeens DM, Sukumaran AV, Williams J, Kilbourn RG, Wang B, Lundeberg T 1997: Drug-induced vasodilation in an in vitro and in vivo study: the effects of nicardipine, papaverine, and lidocaine on the rabbit carotid artery. Plast Reconstr Surg 100: 1475-1481

Goshen J, Wexler MR, Peled IJ 1985: The use of two alpha blocking agents, phenoxyben-zamine and phentolamine, in ointment and injection form to improve skin flap survival in rats. Ann Plast Surg 15: 431-435

Gurlek A, Gherardini G, Cromens D, Joly GA, Wang B, Evans GR 1997: Drug-induced vasodilation: the effects of sodium nitroprusside, hydralazine, and cromakalin on the rabbit carotid artery: in vitro and in vivo study.

J Reconst Microsurg 13: 415-421

Haynes WG, Webb DJ 1994: Contribution of endogenous generation of endothelin-1 to basal vascular tone. Lancet 344: 852-854

Hyza P, Vesely J, Schwarz D, Vasku A, Choudry U, Streit L, Bistoni G, Sukop A 2009a: The effect of blood around a flap pedicle on flap perfusion in an experimental rodent model. Acta Chir Plast 51: 21-25

Hyza P, Vesely J, Schwarz D, Vasku A, Streit L, Choudry U, Sukop A 2009b: The efficacy of magnesium sulfate on resolving surgically provoked vasospasm of the flap pedicle in an experiment. Acta Chir Plast 51: 15-19

Inoue A, Yanagisawa M, Kimura S 1989: The human endothelin family: three structurally and pharmacologically distinct isopeptides predicted by three separate genes. Proc Natl Acad Sci USA 86: 2863-2867

Jurell G, Hjemdahl P, Fredholm BB 1983: On the mechanism by which antiadrenergic drugs increase survival of critical skin flaps. Plast Reconstr Surg 72: 518-523

Kemp PA, Gardiner SM, Bennett T, Rubin PC 1993: Magnesium sulphate reverses carotid vasoconstriction caused by endothelin 1, angiotensin II and neuropeptide -Y, but not that caused by $\mathrm{N}^{\mathrm{G}}$-nitro-L-arginine methyl ester, in conscious rats. Clin Sci 85: 175-181

Khalil AA, Aziz FA, Hall JC 2006: Reperfusion injury. Plast Reconstr Surg 117: 1024-1033

Lantieri L, Carayon A, Maistre O, Evrin J, Hemery F, Torossian JM, Collins ED, Raulo Y 2003: Tissue and plasma levels of endothelin in free flaps. Plast Reconstr Surg 111: 85-91

Masaki T, Sawamura T 2006: Endothelin and endothelial dysfunction. Proc Jpn Acad Ser B 82: 17-24

Moskowitz MJ, Zhang L, Baron DA, Kanner BJ, Tuchler RE, Siebert JW 1995: Transient postoperative stenosis in small-vessel anastomoses. Ann Plast Surg 34: 309-317

Pang CY, Chiu C, Zhong A, Xu N 1993: Pharmacologic intervention of skin vasospasm and ischemic necrosis in pigs. J Cardiovasc Pharmacol 21: 163-171

Russell FD, Davenport AP 1999: Secretory pathways in endothelin synthesis. Br J Pharmacol 126: 391-398

Tsui JC, Baker DM, Biecker E, Shaw S, Dashwood MR 2004: Altered endothelin-1 levels in acute lower limb ischemia and reperfusion. Angiology 55: 533-539

Vachiery JL, Davenport A 2009: The endothelin system in pulmonary and renal vasculopathy: les liaisons dangereuses. Eur Respir Rev 18: 260-271

Wingard CJ, Browne AK, Murphy RA 1995: Dependence of force on length at constant cross-bridge phosphorylation in the swine carotid media. J Physiol 488: 729-739 

Plate I

Hýža P. et al.: Gene Expression ... pp. 453-457

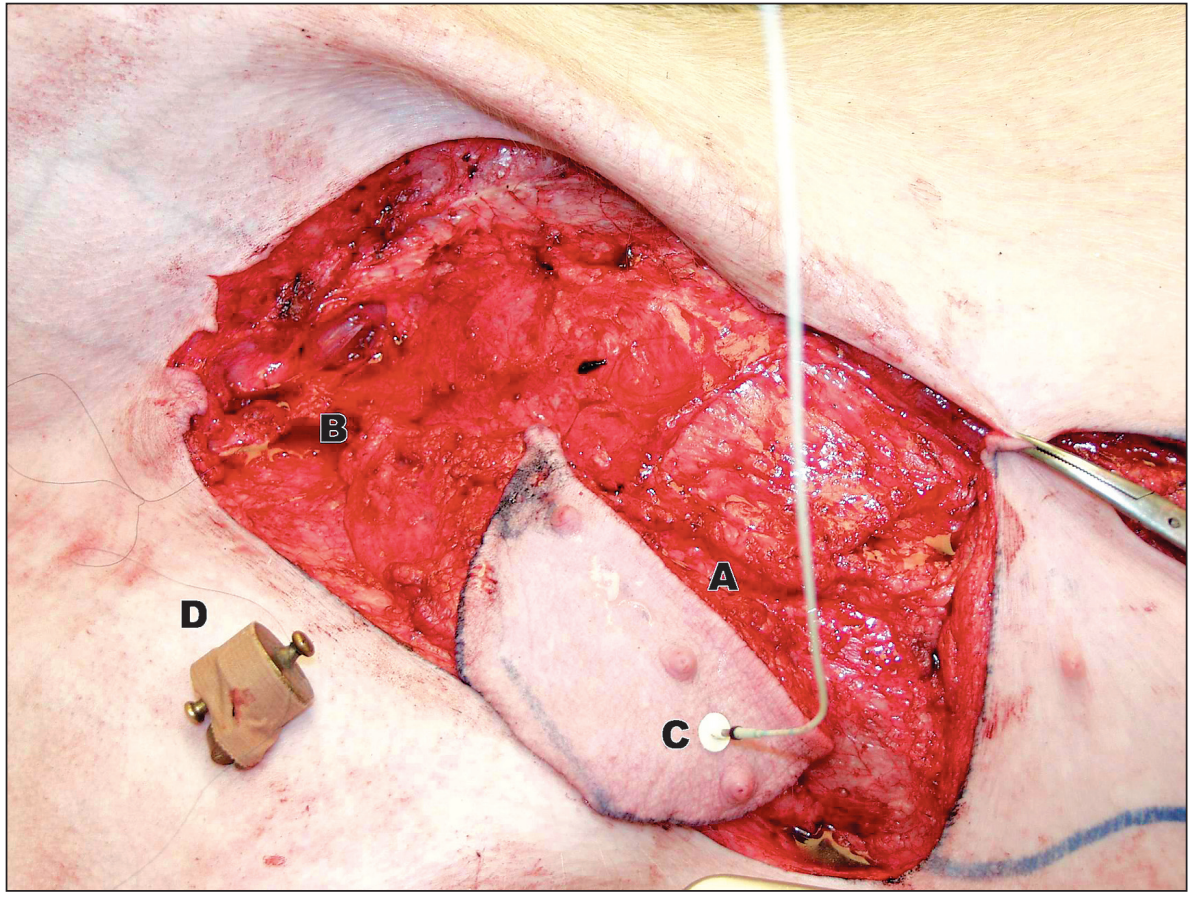

Fig. 1a. The pedicled flap based on the caudal superficial epigastric artery

A - control group, undamaged vessels were taken from the opposite side of the flapthe fat tissue of the flap; $\mathrm{B}$ - the pedicle vessel of the flap - study group; $\mathrm{C}$ - the laser Doppler probe attached to the flap, peripheral blood flow was measured; D - the weight and thread attached to the adventitia of the flap pedicle vessels to be used for vasospasm stimulation. 